\title{
(Mis)-Interpretations of the 1943 Cairo Conference: The Cairo Communiqué and Its Legacy among Koreans During and After World War II*
}

Mark E. Caprio**

\section{Introduction}

On May 2, 1949, President Syngman Rhee [Yi Sŭngman], in a heated discussion with United States Ambassador to the newly formed Republic of Korea (ROK) John Muccio, remarked that the United States had "twice in 40 years... abandoned Korea," coincidently both times by a Roosevelt. The first time was in 1905 when he claimed Theodore Roosevelt ignored Article 1 of the 1882 Treaty of Peace, Amity, Commerce, and Navigation that Korea had signed with the United States. In this article, the United States had promised to "exert [its] good offices on being informed of a third party" exerting oppression on Korea, here, of course, the Japanese. At this time, the United States had not only refused to intervene on Korea's behalf it had also encouraged Japan's placing Korea under its protectorate wing. Then at Yalta in 1945, Franklin Roosevelt allegedly forged a secret agreement with Joseph Stalin to divide the peninsula after the war. Rhee's concern on this occasion, with Communism strengthening its influence to the ROK's north in the Democratic People's Republic of

\footnotetext{
* The author is appreciative of the comments this paper received from two anonymous reviewers. He assumes full responsibility for its content.

** Professor, College of International Communication, Rikkyo University.
} 
Korea (DPRK) and to its west in China, was whether the United States was again abandoning the Korean people in their time of need. Should war break out on the Korean peninsula would the United States drop the ROK like it had just recently "dropped" China?'

Rhee's accusation that Roosevelt and Stalin had forged a secret agreement over Korea aside, at least in the U.S. President's mind, the idea of a liberated Korea enduring a period of multi-state trusteeship had preceded the Yalta conference by over a year. Though the idea was first made public at the November conference in Cairo, Egypt, the president had been voicing this idea from months before the conference. ${ }^{2}$ In Cairo, Roosevelt met with two other Allied leaders, Prime Minister Winston Churchill and Nationalist Chinese leader Chiang Kai-shek, to discuss wartime strategy. He and Churchill would later meet with Stalin in Tehran, Iran immediately following the Cairo meeting to engage the Soviet leader in similar discussions, as well as to gain his consent of the Cairo Communiqué's

1 "Memorandum of Conversation, by the Ambassador in Korea (Muccio)" (May 2, 1949), United States, Department of State, comp., Foreign Records of the United States Diplomatic Papers 1949. Vol. VII, The Far East and Australasia (Washington, D.C.: Government Printing Office, 1976), 1003-1005. Syngman Rhee was convinced that the U.S. and U.S.S.R. had made a secret agreement to divide Korea. He may have had inside information on this, but if such an agreement had been reached it was not made public. The agreement that the two budding superpowers did make on this occasion was for the Soviets to acquire the Kuril Islands of Hokkaido's shores, should they enter the Pacific War before Japan surrendered. Joint War Planning Committee, "Planning for Initial Japanese Occupation Period" (July 30, 1945), Records of the U.S. Joint Chiefs of Staff, RG 218, Box No. 135.

2 Roosevelt mentioned the idea to Anthony Eden when the British Foreign Minister traveled to Washington, D.C. in March 1943. James Matray notes that the president justified trusteeship for Korea, by pointing to its large illiterate and impoverished society, its political and economic backwardness, the totalitarian nature of Japanese rule, and the disunity of the Korean independence movement abroad. James I. Matray, "Civil War of Sort: The International Origins of the Korean Conflict," in The Korean War in Retrospect: Lessons for the Future, ed. Daniel Meador (Lanham: University Press of America, 1998), 143-44. 
contents. Decisions etched into this document set in motion a postwar policy that would later be verified at both the Yalta and Potsdam conferences in 1945, and serve as a foundation for the decisions made at the Council of Foreign Ministers meetings that convened that December in Moscow to resolve outstanding post-World War II issues.

The importance that the Cairo Communique assumed over the years since its December 1943 release to the public suggests that its contents had assumed an important part of the discussions that transpired over the four-day conference. To the contrary, they did not. Indeed, for the most part, Korea's future would be debated over a small part of a dinner meeting attended by two, rather than all three, of the conference participantsRoosevelt and Chiang - held on the evening of November 23. The three controversial words etched into the Cairo Communiqué, "in due course," emerged in the document's third and final draft that the British, who appeared more concerned over reactions of independence leaders within its colonies than with Korea's future, had edited in. ${ }^{3}$

From the time it was made public, Koreans attached more attention to this phrase that compromised the Allied leaders hitherto unprecedented promise of their independence, one that left them scratching their heads as to how it should be interpreted. Its obtuse nature was further confounded by the fact that it did not articulate the views of its authors who before Cairo had given little serious thought as to Korea's postwar future. Demands by Koreans in exile for explanation thus went unanswered by U.S. officials, who at the time were struggling to understand Korea's past and present situation. This paper argues that the most important legacy of this conference is in the hurriedly composed phrase, "in due course," rather than the content of the four-days of meetings. At future conferences, the mere mention of this phrase, or simply Cairo, would suffice to summarize the Allied powers' images of the policy to be implemented in post-

3 The first draft of the Cairo Communiqué included the words "at the proper moment" after Japan's defeat. The second draft replaced this phrase with "at the earliest moment." 
liberation Korea, with little discussion over how that operation would emerge or manifest. Misunderstanding of the phrase by the Korean people, and a lack of understanding on the part of the Allies, as to what this short, ill-conceived phrase actually created confusion, ${ }^{4}$ and consequently chaotic and violent divisions among the Korean people. Thus, understanding the significance of the Cairo conference requires examining this legacy, and particularly the influence that it had, and continues to have, on the Korean peninsula and its residents.

4 The Korean translation of the promise that the three Allied leaders made at Cairo has changed over the years. Contemporary versions, such as those found on Wikipedia, translate the "in due course" phrase as chǒktang han shiki $e$ [at a proper moment]. However, early newspapers tended to leave out the phrase altogether by simply informing that the three leaders were "determined to make Korea free and independent [Chosŏn ŭl chayu t'o tongnip shikkil kyŏlŭi]. See, for example, The Tongnip sinmun [Independent Newspaper] (August 15, 1946). I thank my student, Ho June Jung, for his valuable assistance in working through this rather complicated issue.

5 The most complete record of the Cairo Conference is United States Department of State, comp., Foreign Relations of the United States, Diplomatic Papers: The Conferences at Cairo and Teheran 1943 (Washington, DC: Government Printing Office, 1961). This account of the meetings referenced diaries, memoirs, and monologues available at the time of its compilation It also appended a bilingual report authored by the Chinese delegation. Secondary works on the conference include Keith Sainsbury, The Turning Point: Roosevelt, Stalin, Churchill, and Chiang KaiShek, 1943: The Moscow, Cairo, and Tehran Conferences (Oxford: Oxford University Press, 1986). Recently, research using Chinese documents has appeared that considers Chiang Kai Shek's role in the conference. See Ronald Heifeeman, The Cairo Conference of 1943: Roosevelt., Churchill, Chiang Kai-shek, and Madame Chiang (Jefferson, NC: McFarland \& Company, 2001), (Kindle edition). and Xiaoyuan Liu, A Partnership for Disorder: China, the United States, and their Policies for the Postwar Disposition of the Japanese Empire, 1941-1945 (Cambridge: Cambridge University Press, 2002). The many articles published in Korea on this subject address different aspects of the conference. Those considered for this paper inlcude Pae Kyǒnghan, "Kairo hoedam esǒ ǔi Hanguk munje wa Jiang 


\section{Preparations for Cairo}

The tide of the wars in Europe and Asia changing in the Allied forces' favor by 1943 allowed their leaders the hitherto unprecedented luxury of meeting as a group to discuss primarily wartime, but also postwar, strategies. While Franklin Roosevelt and Winston Churchill had met on several occasions since their initial conference off the coast of Canada in August 1941, the two other Allied leaders had not been invited to join the meetings. Roosevelt, for one, was eager to extend these meetings to include the non-English speaking Nationalist Chinese and Soviet Allies, the armies with which the United States and Great Britain joined on the battlefield. Chiang Kai-shek was livid over Chinese representation not being invited to the January 1943 meeting that the Anglo-American leaders held in Casablanca, Morocco. More so than the British and Soviet leaders, Roosevelt deemed Chiang's inclusion of utmost importance to ensure that the Chinese dedicated their human and material resources to the war at hand, rather than to a later war they anticipated having to fight with the Chinese Communists. From 1942, two high-profile visits to the U.S. by Chiang's brother-in-law, Foreign Minister T. V. Song, and Song's sister and Chiang's wife Madame Chiang [Song Mei-ling], entertained the idea of Chiang and Roosevelt possibly holding a meeting at some time in the future. ${ }^{6}$ Ronald Heiferman suggests that Song's visit enabled the Chinese official to use Chiang's non-invitation to the Casablanca conference to

Jieshi" [Jiang Jieshi (Chiang Kai-shek) and the Korea Problem at the Cairo Conference], Yǒksa Hakpo 224 (December 2014): 305-35; Wada Haruki and Pak Ǔnjin, "Kairo sǒn'ǒn kwa Ilbon yǒngt'o munje" [The Cairo Declaration and Japanese Territorial Issues], Yǒn'go haebang yǒn'gu 5 (June 2013): 86-111, and Chŏng Yong Uk,“Yŏkpinondan: 1945nyŏn mal 1946nyŏn ch'o sint'ak t'ongch'i p'atong kwa migunchŏng migunchŏn ŭi yŏron kongjak ŭl chungsim ŭro," [The United States Military Government and Fluctuations in Trusteeship Administration from Late 1945 to early 1946: A Focus on U.S. Public Opinion Maneuvering] Yǒksa Pip'óngsa (February 2003): 287-322.

6 Heiferman, The Cairo Conference of 1943, loc. 572. 
China's advantage: "The ghost of Casablanca haunted the Washington Conference. This worked to the advantage of Soong who was able to extract concrete promises from Roosevelt and Churchill of more assistance."7

By including Chiang in the Cairo meetings Roosevelt also sought to strengthen his postwar vision of "four policemen" patrolling the global environment to extinguish belligerent local fires before they turned global. Toward this end he envisioned China joining the Soviet Union, Great Britain, and the United States to form this quartet. His vision of China's postwar role as a global power was not matched by either Stalin or Churchill who both saw China as weak. Stalin gave a number of excuses to avoid his having to travel to Cairo. Perhaps the more credible was his reluctance to sit alongside the leader of a country then at war with Japan. ${ }^{8}$ The Soviet Union had signed a non-aggression pact with Japan in 1941, two years after their short border skirmish had ended. He feared that his attendance at such a conference might provoke retaliation by the Japanese, most likely at the Soviet Far Eastern military outpost at Vladivostok. Stalin did dispatch his Deputy Foreign Minister, Andrey Y. Vyshinsky, who participated in discussions with British and U.S. officials regarding strategies on the European theater. As mentioned above, in Tehran, the Soviet leader was briefed on the discussions held in Cairo, and asked his views on the Communiqué's content. ${ }^{9}$

In addition to his lack of faith in China's capacity as a postwar global

7 Ibid., loc. 625.

8 Stalin also used the excuse that he felt obligated to remain close to the battlefields at this critical time in the war with Germany. Another possible reason for Stalin's decision not to travel to Cairo was his alleged fear of flying. His flight to Tehran apparently was the first, and last, time he boarded an airplane. Keith Sainsbury considers security measures to have influenced Stalin's decision. Tehran at the time had a Soviet military presence that Cairo lacked. Sainsbury, The Turning Point, 124.

9 Stalin nodded his approval at a meeting on November 30 over lunch with Roosevelt and Churchill. See United States Department of State, comp, "The Conferences at Cairo and Tehran," 566. 
leader, Churchill harbored other reasons for not welcoming Chiang's presence. ${ }^{10}$ The British prime minister valued his monopoly of the president's ear, an image that Roosevelt sought to break by inviting the other two leaders to the conference table. He also feared that Chiang's presence would shift the meeting's agenda away from the campaigns in Europe and toward those in Asia. Priority, he believed, should be devoted to the former battles. ${ }^{11}$ His concerns were justified to an extent - the participants did spend more time than he felt necessary on Operation Buccaneer, a plan to engage the Japanese in Burma from the Bay of Bengal. However, the military officials at the conference found plenty of time to discuss the European campaigns. Chiefs of Staff meetings attended by British and U.S., but not Chinese, military brass gathered on a number of occasions to discuss wartime strategy in Europe. A third reason for Churchill's objections to Chiang's presence was perhaps for Churchill the most troublesome: the fear that discussions might drift toward the postwar status of former Chinese territories that the British had annexed into its empire over the years. The prime minister had been able to skirt this issue after his meeting with Roosevelt in August 1941 by claiming that the "selfdetermination" pledge that they had included in the Atlantic Charter did not involve Britain's Asian possessions. It was, after all, an Atlantic Charter. Chiang's presence risked the Alliance extending the Charter to incorporate Asian, and thus British, territories. ${ }^{12}$

10 Heiferman writes that T.V. Soong, in a March 1943 cable to Chiang, wrote, "Churchill 'characteristically' omitted China when speaking of the Allies." See Heiferman, The Cairo Conference of 1943, loc. 594.

11 In volume five of his six-volume history of World War II, Churchill dedicated a chapter to the Cairo conference but included little on the proceedings of the meetings, devoting more print to the Thanksgiving dinner that Roosevelt hosted. He did note the unfortunate result in the inclusion of Asian issues. See Winston Churchill, The Second World War: Closing the Ring (London, UK: Cassell \& Company 1951), 289.

12 Roosevelt, from the beginning, understood this agreement as one with universal implications despite Churchill's limited understanding of its parameters. The Cairo 
Chiang arrived at the meetings better prepared to discuss postwar issues than his Anglo-American counterparts. Prior to traveling to Cairo, he had commissioned two position reports on the topic of former Chinese territories that the Japanese had acquired from China in 1895, following the first Sino-Japanese War. These reports also considered other areas, such as the Ryukyu Islands and Korea, territories over which Qing China had competed over with Japan, but historically had never occupied as a part of China proper. ${ }^{13}$ Chiang also brought to the conference concerns over Soviet involvement in postwar Asia, a point which he and other Chinese officials had been voicing concern for over a year. ${ }^{14}$ His participation in the conference served as a turning point in Chinese relations with the global powers as, from the mid-nineteenth century these states had lined up in competition over China, while tearing off pieces of its territories and declaring the country "open" to foreign exploitation.

President Roosevelt carried his own agenda to the conference rather than rely on information from State Department reports, as was typical of his way of doing things. ${ }^{15}$ As mentioned above, his main concern was that the alliance evolved into a comprehensive four-state effort, rather than being misperceived as a limited Anglo-American affair. Keith Sainsbury explains Roosevelt's concern as follows:

Communiqué came to be known in certain circles as a Pacific charter.

13 The two reports were compiled by the Junshi weiyuanhui canshishi [Office of the Secretary of the Military Affairs Committee] and the Guofang zuigao weiyuanhui mishuting [National Defense High Committee Private Secretary Agency]. Pae Kyǒnghan, "Kairo hwidang esǒ ǔi Hanguk munje wa Jiang Jieshi," 308-12.

14 Liu, A Partnership for Disorder, 100, 107-11. Liu informs that Chiang entered into his diary his having cautioned the president on Soviet involvement at their meeting. (Ibid., 143).

15 One primary figure on State Department postwar planning committees, Hugh Borton, recalled that "there had been no direct contact between those persons in the Department of State working on Far Eastern problems and those who drafted the Cairo Declaration." Hugh Borton, "American Presurrender Planning for Postwar Japan," Occasional Papers of The East Asian Institute, Columbia University (1967): 12. 
Firstly the conference should not be the Anglo-American "gettogether" before Tehran and, in particular, not the private conclave with Churchill that the latter had wished; and secondly that Far Eastern problems should dominate the agenda and permit the British relatively little time to press their case on Overlord and the Mediterranean. ${ }^{16}$

Roosevelt also aimed to push his ideas on imposing postwar trusteeship administrations on liberated peoples, an idea that his administration had inherited from U.S. President Woodrow Wilson's post-World War I mandate system. His ability to do so would be enhanced should the meetings extend to include a third or fourth party to counter the objections he anticipated from Churchill whose mood turned ugly at any mention of policy that suggested the dismantlement of the British empire. ${ }^{17}$ The president consistently pressed this issue before, during, and after the Cairo and Tehran conferences. At Cairo, he specifically mentioned the peoples of Korea and the former French Indochinese (present-day Vietnam) colony, then both under Japanese control, as appropriate cases for postwar trusteeship guidance. The U.S. president estimated that these occupations would require decades to complete.

\section{Negotiating Northeast Asia's Future}

Chiang's invitation to Cairo would be the last such invite that he would receive over the duration on the war, and thus Asian issues not be dis-

16 Sainsbury, The Turning Point, 169.

17 One often-quoted example was when Churchill exploded in anger when Roosevelt broached the idea of international trusteeship for colonies, including those of the British empire, at the Yalta Conference in February 1945. See, for example, Warren F. Kimball, Forged in War: Roosevelt, Churchill, and the Second World War (New York: William Morrow and Company, 1997), 314. 
cussed in great detail at future meetings until after Germany's defeat in May 1945. The Cairo meetings debated whether the Allies would approve Operation Buccaneer and confront the Japanese from the Bay of Bengal, off the coast of Burma(Myanmar). Roosevelt understood this plan as a way to appease the Chinese leader. Churchill, on the other hand, argued against the plan: The European war had to remain top priority; widening operations in Asia would divert precious military equipment from this front, specifically from operations planned to engage the German armies from northern France (Operation Overlord) and from the Mediterranean Sea (Operation Accolade). Thus, the majority of discussions on wartime strategic at Cairo that involved the Chinese participants argued over the logistics of this operation. The three leaders parted without definite answers to questions raised over this plan. Churchill would later persuade a reluctant Roosevelt to withdraw his support for the plan thus forcing the president to renege on his promise to Chiang to support it. ${ }^{18}$ It is understandable that these discussions, due to their sensitive wartime strategy content and their lack of conclusiveness, did not receive mention in the final conference Communiqué.

It was at the November 23 dinner meeting between Roosevelt and Chiang where the most important points of the Communiqué were discussed. Here the two leaders focused primarily on postwar Northeast Asia. It was Chiang, rather than Roosevelt, who dominated the discussion. Accompanying the two leaders at this meeting were the president's most trusted adviser, Harry Hopkins, Nationalist China's former Foreign Minister, Dr. Wang Chung-hui, and Chiang's wife, Madame Chiang, who interpreted for her husband. ${ }^{19}$ Displaying a confidence that the Allied forces would eventually emerge victorious over Japan, the ChiangRoosevelt discussions considered two postwar issues: the future of Japan

18 See discussion in Heiferman, The Cairo Conference of 1943, Chapter 11.

19 Xiaoyuan Liu's A Partnership for Disorder examined several Chinese documents, including Chiang's diary, in his treatment of the conference. His research uncovered discrepancies between the Chinese record and other sources. 
and its imperial possessions. Regarding the former, the Roosevelt was interested in Chiang's views on how the Allies should handle the Japanese emperor's postwar future - this should be left for the Japanese people to decide; whether China could participate it an occupation of Japanif in a supporting role; and whether Japan should pay war reparationsyes, but through material, rather than financial, payments. ${ }^{20}$ Regarding Japan's imperial possessions, the two leaders agreed that former Chinese lands gained by Japan through war were to be returned to China. These included those acquired as part of the peace settlement that ended the Sino-Japanese war in 1895, namely Taiwan and the Penghu (Pescadores) Islands, as well as those territories that it had more recently gained: the four northeastern provinces (Manchuria) and the Liaotung Peninsula.

The two leaders extended their discussions to include other areas. Roosevelt proposed that the port of Dairen in northeast China be converted into an international port to satisfy the Soviet Union's craving for an icefree port to serve its Asian interests. He also inquired as to how China saw the future of Okinawa (Ryukyu Islands): Would China claim this archipelago as well? Chiang remarked that since these islands had never been part of China, he saw no reason to claim them as Chinese territory. Roosevelt then suggested that the two states jointly occupy the islands after the war. Either way, the two leaders agreed that this territory would not remain a part of Japan after the war. ${ }^{21}$ They also briefly touched on the future of Indochina (present-day Vietnam), Hong Kong, and Thailand. Both agreed that the French should not be allowed to return to their Indochinese colony even after the Allies succeeded in driving out the Japanese; the French record in governing this territory had been, after all, abysmal. $^{22}$ They also agreed that Hong Kong should be returned to China, even if the Chinese chose to re-lease it back to the British; Roosevelt cau-

20 As outlined in the Chinese report, appended to United States Department of State, comp, "The Conferences at Cairo and Tehran," 324.

21 Ibid., 324.

22 Sainsbury, The Turning Point, 206. 
tioned Chiang against formally raising this sensitive issue with Churchill as at this point it would do more harm than good. The president did, however, broach the topic in private conversation with the British prime minister in Cairo, ${ }^{23}$ and on future occasions. Thailand, they agreed, should be granted independence. Although technically sovereign at this point, the kingdom confronted a strong Japanese presence at the time.

Korea received minimal attention, at least as recorded in the FRUS report. Chiang came to Cairo with the notion that Korea should be granted its independence soon after the war finished, a point he addressed at their meeting. The report notes that Roosevelt supported this view, with the caveat that Korea would endure a period of trusteeship after its liberation from colonial rule to prepare the people for complete sovereignty. Perplexing was Roosevelt's claim in a post-conference report that the Soviet Union had agreed with a United States' assessment that because the Korean people were ill-prepared to handle their independence, they "should be placed under a 40-year tutelage." Although Stalin reportedly nodded his approval to a trusteeship arrangement in principle, there appears to have been no document that verifies Roosevelt having proposed decadeslong trusteeship to Stalin or any of the Allies. ${ }^{24}$ If there had been such an agreement it would have had to have been made in private conversation and thus off the record. Apparently, Chiang did not have much to say regarding postwar Korea during discussions on the content of the Communiqué. As we shall see, forcing the two conflicting aspirationstrusteeship and independence-into a single sentence of the Communiqué succeeded in injecting confusion into Korean postwar visions.

The report on the "Cairo Communiqué" contains the texts of the document's three major drafts. It informs that the United States provided the

\section{Sainsbury, The Turning Point, 185.}

24 This is noted in a footnote attached to a report appended to United States Department of State, comp, "The Conferences at Cairo and Tehran." FRUS report See Wilson Brown, "Minutes of a Meeting of the Pacific War Council" (January 12, 1944), 868-69. 
first two drafts and the British the third. Although China's participation in this process appears to have been minimal, the document's contents closely reflect much of what Chiang Kai-Shek had expressed in his meeting with Franklin Roosevelt. The final product's concentration on Japan's postwar is understandable; Japan, after all, was the common enemy of all three of the participants. The document is, at the same time, misleading in that it reflected very little of the discussions that occupied the conference meeting agenda. In it the leaders condemned Japan for turning the former German island possessions in the Pacific Ocean that it had received through the post-World War I mandate system into military bases, and for annexing lands that it had "treacherously stolen" from China. As Chiang had requested earlier, Japan was to return former Chinese territories to China following its expected defeat. This part of the Communiqué's original draft read as follows:

We are determined that the islands in the Pacific which have been occupied by the Japanese, many of them made powerful bases contrary to Japan's specific and definite pledge not to militarize them, will be taken from Japan forever, and the territory they have so treacherously stolen from the Chinese, such as Manchuria and Formosa [Taiwan], will of course be returned to the Republic of China.

The second draft added the following: "All of the conquered territory taken by violence and greed by the Japanese will be freed from their clutches." The British version deleted this sentence, but retained its spirit in the following passage:

It is their [the Allies] purpose that Japan shall be stripped of all the island of the Pacific which she has seized or occupied since the beginning of the first World War in 1914, and that all the territories Japan has stolen from the Chinese, such as Manchuria Formosa, shall be restored to the Republic of China. Japan will also 
be expelled from all other territories which she has taken by violence and greed.

This draft added that the Allied forces would "continue to persevere in the serious and prolonged operations necessary to procure the unconditional surrender of Japan." The demand that Japan's surrender must be "unconditional" simply extended a demand that the Anglo-American Allies had made on Germany the previous January in Casablanca. This pledge also secured Chiang's promise that his armies would continue to engage Japan until it surrendered, that it would not seek a separate peace with this enemy before then.

The Communiqué's brief treatment of Korea, which occupied one short but crucial sentence, suggests that the peninsula's future had occupied an important part of the conference discussions. The Korean people most certainly would welcome the leaders' stated intention to deliver to Korea its independence. This promise, after all, represented a 180- degree change by the Allies who in 1910 had welcomed and supported Japan's decision to annex the peninsula. However, Koreans would ponder, what was to be made of the Communiqué's inclusion of the "in due course" qualification? They were of course not privy to the evolution that the phrase had underwent from the Communiqué's initial version. The original U.S. drafts, underwent a number of changes between November 24 and 25. The first draft, which was authored by President Roosevelt and his aid Harry Hopkins, read as follows:

We are mindful of the treacherous enslavement of the people of Korea, and are determined that that country, at the earliest possible moment after the downfall of Japan, shall become a free and independent country. (italics added)

The United States side then replaced the "at the earliest possible moment" phrase with a slightly vaguer one: "at the proper moment." Finally, on the conference's final day, the British contingent changed the U.S. 
phrasing to the more obtuse and troublesome "in due course" phrase, while editing out the "after the downfall of Japan" segment. Thus, the Communiqué's final official text read as follows:

The aforesaid three great powers, mindful of the enslavement of the people of Korea, are determined that in due course Korea shall become free and independent. (italics added) ${ }^{25}$

This sentence was not the only part of the three versions of the Communiqué that received attention, but for Koreans this was where they focused their attention. Just why the British contingent edited in the "in due course" phrase is unclear. Winston Churchill had previously demonstrated little interest in Korea, or for that matter the Asian theater in general, save for his efforts to dissuade advancement of Operation Buccaneer and to deflect mention of territories in Asia that his country still governed, and those it planned to recover after Japan's defeat. One possible explanation is that a non-qualified pledge to deliver Koreans their independence might very well have encouraged independence groups in the British Empire to demand a similar pledge on their behalf. ${ }^{26}$

In the end, each of the three leaders gained from the conference. Churchill succeeded in protecting his country's Asian possessions from

25 The three versions of the Cairo Communique are included in United States Department of State, comp, "The Conferences at Cairo and Tehran," 401-404. Additional alterations appear elsewhere, including the deletion of the names of the participants that were included in the drafts prepared by the United States.

26 Churchill had faced pressure from political leaders in Britain and the colonies after the August 1941 Atlantic Charter that he joined President Roosevelt in signing contained a clause calling for a people's right to self-determination. During the war he faced similar pressure from independence groups such as Quit India that protested British rule. Indian support for the British military role in the war made it imperative that they continued to provide men and materials to battle the Axis powers. See Arthur Herman, Gandhi and Churchill: The Epic Rivalry that Destroyed an Empire and Forged Our Age (London: Bantam, 2009), Chapters 27 and 28. 
appearing on the conference agenda. Discussions on a possible Asian operation had, to his regret, occupied their meeting time. But his military staff had been able to delay any finalization of these plans, which would eventually be scrapped anyhow. Chiang Kai-shek secured Allied promises that former Chinese holdings would be returned to China after the war. He also left Cairo believing that the Allies would soon attack the Japanese from off the Burmese coast. And finally, Franklin Roosevelt was able to extend participation at Cairo, and later Tehran, to include non-AngloAmerican participants. He also had secured Chiang's promise to exert full effort in the war against Japan. This latter success was most important to the president as China's premature exit from the war would have freed tens of thousands of Japanese troops to joining the war against the United States across the Pacific battlegrounds. In Tehran, Roosevelt received a third success in Joseph Stalin's promise to join the Pacific War soon after Germany's defeat. ${ }^{27}$

\section{U.S. Reactions to the Cairo Communiqué}

The proceedings of the conference itself were conducted in secrecy. During the meeting days the leaders issued no press releases to detail the conference's agendas or whether the three Allied leaders were making progress toward their goals, which apparently were also kept secret. The press was treated to photo sessions where the participants gathered outside the conference building and engaged in conversation with each other as the photographers took motion and still pictures under the Cairo sun. These photo-opts sent the misleading message that the Allied leaders conducted business under congenial conditions, thus hiding confronta-

27 United States Department of State, comp, "The Conferences in Cairo and Tehran," 489. Stalin had previously informed U.S. Secretary of State Cordell Hull of his intention to enter the Pacific War at a foreign ministers meeting that was held in Moscow in October 1943. Sainsbury, Turning Point, 110. 
tions that broke out in the meeting rooms, particularly between the British and Chinese participants. ${ }^{28}$ The Communiqué itself was not made public until December 1, after Churchill and Roosevelt had briefly discussed it with Joseph Stalin in Tehran. The reaction to its contents was mixed. One issue of the Far Eastern Survey published by the Institute of Pacific Relations of the American Council carried an overly generous critique of the conference that focused on decisions made regarding Japan's fate. It congratulated the Anglo-American participants (but not China) for finally drafting "plans for the overthrow of Japan." It also noted the determination the Allies showed in declaring their intention to strip Japan of its "illgotten empire" to ensure that it would not re-emerge as a threat after defeat. The leaders' treatment of Japan came with an "immense moral value... from a convincing determination on an international scale that crime does not pay." The article next applauded the decisions that the leaders made regarding Korea's post-liberation fate, suggesting that the country's postwar fate had been more of an issue at the conference that it actually had.

Of considerable political value also is the pledge that Korea "in due course shall become free and independent." Although the Korean nationalists are protesting the insertion of the qualifying phrase "in due course," every student of the Korean situation is painfully aware of the practical difficulties of restoring this unhappy country to full independence. In view of these difficulties, the conference's pledge should serve to reassure not only Koreans but other subject nationalities that the principles of the Atlantic Charter are considered applicable to Asia as well as to Europe. ${ }^{29}$

28 See, for example, "The Cairo Conference (1943)," at <https://www.youtube.com/w atch?reload=9\&v=TT16RC43h7g $>$ (accessed February 4, 2022).

29 Maxwell S. Stewart, “The Cairo Declaration," Far Eastern Survey 12, no. 25 (December 22, 1943): 241-42. 
A second article that appeared in The Christian Century was less generous. The magazine highlighted a fundamental weakness that it saw in the Cairo Communiqué: its "silence" over the fate of the "white colonies." It explained:

... nothing is said in the Cairo declaration about the future disposition of the former white colonies in Asia now overrun by Japan. ... It must suffice here to say that to go to such lengths in announcing the way in which Japan is to be utterly stripped of all her colonies, including territories taken as long as forty-eight years ago, and then by silence to leave the implication that lost colonies are to be restored to Britain, France and Holland-to do this to confirm the Oriental mind in its suspicion that one purpose for which we are fighting in Asia is to wipe out any non-white empire and to rescue and restore any threatened white empires. ${ }^{30}$

This comment reflected the discrepancy between the meeting and the Communiqué's contents as the "white colonies" had received brief mention in the former but not the latter. But the point that the leaders' freely condemned Japan's actions while remaining silent on the "white" colonized territories, many also acquired as war booty, was more than justified. For sure Japan was just one of a number of colonial powers, including the U.S. and Britain, that had used war as a tool to expand their own empires.

Another perspective by the scholar Andrew Grajdanzev offered a different view regarding the Communiqué's conclusions on Korea by inquiring on the content of a post-liberation occupation. Grajdanzev, who was affiliated with the Institute of Pacific Relations, wrote predominantly on colonial matters, and particularly on Korea. In 1944 he argued that Allied fears of renewed competition for influence over the peninsula would transpire, but only if one particular state gained a hegemonic position on the

30 "Cairo and Tehran" The Christian Century 60 (December 15, 1943): 1465. 
peninsula upon Korea's liberation.

The geographic situation of Korea is such that every neighbor is interested in her independence. Korea, in Japanese hands, as the history of the last twenty years clearly shows, is a threat to Russia and China. Korea in Russian hands would be a threat to Japan and to the whole strategic position of China and Manchuria. Korea in the hands of China would be a threat to Japan and to the Russian position around Vladivostok. It is to the interest of all three countries that Korea should be independent.... With a strong Russia and a strong China, Korea has no need to fear that her independence will be lost.

He added that the "task of Korean statesmen is to establish friendly relations with all neighbors, to prove to them that a free Korea is the best guarantee of peace in this part of the world." 31 Wartime reports on Korea drafted by the U.S. State Department cited Grajdanzev's writing, but did not apply his ideas to the postwar policy that they formed. ${ }^{32}$

\section{Japanese Criticism's to the Cairo Decisions}

The Japanese, as would be expected, had nothing positive to say regarding the Cairo Conference; nor did it fully report on the Cairo Communiqué in their media outlets. The Foreign Ministry criticized the enemy nations' duplicity in their language. In a report drafted, just one week after the document had been made public, it criticized the enemy for

31 Andrew Grajdanzev, Korea Looks Ahead (New York: American Council, Institute of Pacific Relations, 1944), 54-56.

32 See, for example, Chapter ten of the report Joint Intelligence Study Publishing Board, "Joint Army-Navy Intelligence Study on Korea," in Yi, ed., Haebang chŏnhusa charyojip: Mikunjŏng chunbi charyo, 292. 
shouting justice, humanity, benevolence, and righteousness in contradiction to their actions. The Allied alliance insists on maintaining "open doors of equal opportunity" but treats Asian peoples unequally. They bragged about treating Japan as a "third rate country (santō koku)," but uttered not a single word regarding the liberation of peoples they had colonized for so long. To the contrary they appeared more interested in returning to a time prior to Japan's arrival, when these colonial powers had oppressed Asian peoples. Wada Hideki adds that such views were also held by Prime Minister Tōjō Hideki. ${ }^{33}$ The Japanese press, being the primary outlet for commentary on the Communiqué, was rather uniform. It criticized Allied demands that Japan surrender unconditionally - an "insulting resolution" to which Japan would never agree. Such statements revealed their "arrogance" (gōman), while suggesting their harboring "anxiety over their senseless reality" (hibō jitsugen ni shōryo). Newspapers reiterated the Japanese Foreign Ministry claims that the Communiqué demonstrated the Allied powers' ultimate goal as being to turn Japan into a "third-rate country." The purpose behind their declarations was to "force East Asian eyes to bend downward" in deference toward them. ${ }^{34}$

Information in the colonial-based press appeared later, and in less quantity, than in the homeland newspapers. The Keijo nippō, a Japaneselanguage newspaper published in Seoul, did not carry its first article on the conference until December 10, a week after the story first appeared in the Japan-based media, and even two days after it had reported on the Tehran conference. ${ }^{35}$ This media repeated the accusation that the Allied

33 Wada Haruki, “Kairo sǒn'ǒn kwa Ilbon yǒngt'o munje," 103.

34 "Kairo kaidan, Teki gōmanno ketsugi-Senkyoku hatan wo koto [The Cairo Conference and Enemy Arrogance. A stopgap measure for a Failed War Situation], Asahi shinbun (December 1, 1943).

35 "Kairo kaidan to beieino yabō" [U.S.-British Aspirations and the Cairo Conference], Keijō ilbō (December 10, 1943), Regarding the Tehran conference see "Teheran kaidan: Shōhō soren ga shidouteki na yakuwari [The Tehran Conference: A Detailed Account of the Soviet Union's Leadership Role], Keijo ilbo (December 8, 1943). 
forces planned to turn Japan into a "third-rate country," and their demands that Japan surrender unconditionally. ${ }^{36}$ Finally, the Japanese newspaper in Taiwan, the Taiwan nichi nichi shinbun, described the decisions made in Cairo as "hysterical" (hisuterikku ketei). ${ }^{37}$ Much of this coverage by the Japanese media positioned stories of Japan's war successes alongside its criticism of the decisions made in Cairo. Lacking in this press coverage was any indication of the fate of Japan's imperial holdings after its surrender. Was this a result of the Japanese press not having access to the Communiqué? Or did self-censorship prohibit the possibility of the document ever reaching the public? A keen reader, however, might very well have been able to mentally fill in this missing information by reading between the lines of the limited information that the press did provide. We might also suspect that this neglected information filtered into the homeland and the colonies through alternative channels.

\section{The Dilemma Facing Exiled Koreans: Promises of Korean Independence, but Delayed}

One channel from which this information most likely flowed was that operated by overseas Koreans who had begun to leave Korea from the late nineteenth century. Many Koreans who relocated to the United States, China, and Russia, were active in their independence movement activities, particularly from the early 1920s and 1940s. In their commentary on the Cairo Communiqué these Koreans predictably focused on the obscure "in due course" phrase, which they soon understood to indicate a tutorial period that Korea would have to endure following its liberation from Japa-

36 "Nihon no ketsui ha rōkoteki hazure no Kairo kaidan" [The Cairo Conference's underestimation of Japan's invincible resolve], Keijō ilbō (December 10, 1043).

37 "Teheran kaidan bakusai" [The Tehran Conference blast] Taiwan Nichi-Nichi Shinbun (December 10, 1943). 
nese rule and before the Allies would honor their promise to deliver independence to the peninsula. ${ }^{38}$ Indeed, Koreans had suspected this possibility even before the three leaders had met in Cairo. In August 1943, for example, Tji So-wang [Cho So-ang], Foreign Minister of the Korean Provisional Government (KPG) centered in Chongqing, China, commented on what he saw as a contradiction between trusteeship and previous pledges, such as U.S. President Woodrow Wilson's declaration of a people's right to self-determination that he included in a 1918 speech, and a more recent renewal of this declaration when U.S. President Franklin Roosevelt met with British Prime Minister Winston Churchill at their August 1941 meeting off the Canadian coast. Tji's argument appeared a few months prior to the Cairo meeting in the Honolulu-based Herald Pacific Weekly.

Representing the Korean Provisional Government and voicing the sentiment of the entire Korean people at home or abroad, I have the honor to state that all Koreans desire absolute independence and therefore are opposed to any understanding or suggestions concerning postwar international guardianship of Korea as much does not accord with the Atlantic Charter and is against the will of the twenty-three million Koreans and ever endangers peace in Eastern Asia. ${ }^{39}$

Overseas Koreans stepped up their campaign against trusteeship soon after the Cairo Communiqué had been made public. These Koreans would devote their efforts over the last months of the war, and into the postwar

38 Yi Chun-sik dates Koreans speaking out against the possibility of such a period from as early as the summer of 1942 in his Kim Kyu-sik [Kim Kyu-sik], (Seoul: Yoksa kongkan, 2014), 146-50.

39 "Korean Gov. Informs FDR, People want no Mandatory for Korea" (August 4, 1943), National Herald Pacific Weekly, in Internal Affairs of Korea (1940-1944), Migukkukmu sǒng Hanguk kwanke munsǒ [Papers of the United States Department of State, Korea], vol.3 (Seoul: Wonjumunhwasa, 1993), 509. 
period, to nag U.S. officials for explanation as to the meaning behind the "in due course" phrase. Initially, political leaders dispatched letters to the Allied leaders in appreciation for their recognition of Korea's right to independence. Kilsoo Haan (Han Kilsu), representing the Sino-Korean People's League, predicted in a letter to Winston Churchill that "[a]s soon as millions of patriotic Koreans in Korea, Japan, Manchuria, and occupied China learn of the solemn and sacred promise [of Korean independence] there will be plenty of fireworks behind Japan's strategic areas." ${ }^{40}$ In Hawaii, the Central Committee Chair of the Dongjin Hoi (Tongjihoe, Comrades Society) wrote, "The decision of the Cairo Conference encourages every Korean to fight against our common enemy Japan. The Dongjin Hoi Conference in Honolulu extends its deepest gratitude to Prime Minister Churchill, President Roosevelt, and Generalissimo Chiang." 41 Similarly, the Voice of Korea, published in Washington. D.C., offered a positive reaction to the news of the Allies promising Korea's independence in an article authored to commemorate the second anniversary of Japan's attack on Pearl Harbor, a development that many Koreans saw as the beginning of the end of Japanese rule over their country. The newspaper trumpeted as follows:

When the people in Korea hear [of] this epoch-making decision, they will weep with delight. They will redouble their efforts in destroying our most treacherous enemy. On the anniversary of Pearl Harbor, Koreans everywhere rejoice that justice has finally been done to them. They will prove themselves worthy of deserving

40 "Haan to Churchill" (December 2, 1943), British Foreign Office: Japan Correspondence, 1941-1945, File 1945 (Reel 3), British Foreign Office Papers, Japan Diet Library. Haan had developed quite a reputation among members of the Foreign Office. Scribbled in pen beside his missive was the warning, "Best to ignore this communication. If we give the writer an opening he will bombard us with letters."

41 "Telegram from Dongjinhoi in Honolulu to Prime Minister Winston Churchill" (undated but most likely written before January 6, 1944), Ibid. 
their independence. They will fight on the side of the United $\mathrm{Na}$ tions until Japan is crushed and they are absolutely free!

When You Remember Pearl Harbor, Remember Korea! ${ }^{42}$

(italics in original)

Words of caution accompanied these words of acclaim: the agents of such declarations almost never supported them with appropriate action. Haan wrote to President Roosevelt for clarification on "the Three Powers promise to free Korea [as] announced [on] Dec. 1." ${ }^{43}$ Korea's competitive press also contributed its concerns. One article that appeared in the Los Angeles-based Korean Independence, titled simply" In Due Course," aimed to raise awareness rather than to criticize. The article began on a positive note:

This is the first time in the history of diplomatic conferences that the problem of Korea has ever been discussed and discussed realistically.... there never was a time when the allied leaders have jointly and officially pledged themselves to liberate Korea as they did at the Cairo conference. For this reason, this declaration of the big three pertaining to Korea gives new hope and inspiration to Koreans everywhere, who are fighting for the restoration of their lost country.

It then advised caution. Time will tell just how willing the Allied powers are to back their generous words with meaningful action.

But it is one thing to promise and another thing to keep the promise. It is not uncommon in the history of international politics

42 "Pearl Harbor and Korea," Voice of Korea (December 7, 1943).

43 Haan to Roosevelt" (December 14, 1943), in Internal Affairs of Korea (1940 1944), vol. 4, 98-99. Haan was reacting to a December 2 article that had appeared in the New York Times explaining "in due course" as trusteeship. 
that a nation or nations break their pledges and promises without scruples, and always find some excuse for not keeping them. These excuses are possible for the very simple reason that diplomatic languages are often vague and general in nature. For example, in the above-mentioned text of the Cairo agreements, we read that "in due course" Korea shall become free and independent. The expression "in due course" is very indefinite and subject to different interpretations. It may mean that Korea will be made independent immediately after the war, or sometime in the future when things are convenient. ${ }^{44}$

Koreans also contextualized the Communiqué in historical terms. James S. Shin of the Washington, D.C. based Korean-American Council remarked that the promise of Korea's eventual independence offered the United States the opportunity to atone for its past oversights regarding Korea. Here he charged that those who fought for freedom in the U.S. in 1776 would "turn over in their graves for the shameful acts of 1905," when their country turned a blind eye to Japanese violations of the Korean people's freedom when they forced the Eulsa Treaty upon the Korean government. At this time the U.S. neglected a promise that it had made in 1882, when it negotiated with Korea the Treaty of Amity, Peace, Commerce, and Navigation where it had vowed to protect Korea against outside invasion. Shin also found paradoxical the U.S. demonstrating its morals in freeing its slaves in 1865, but in 1905 it turned a blind eye to the Korean people when they were rendered "slaves of the Japs" after the conclusion of the Treaty of Portsmouth, an agreement that the U.S. negotiated with the Russians and the Japanese to end their war. Its recent promise of freedom to enslaved peoples delivered a "glimmer of hope that more than one billion people living and existing in that part of the world where all nations, be they large, or small, strong, or weak, will be entitled

44 Key H. Chang," "Korea's Freedom and Independence Promised," Korean Independence (December 4, 1943). 
to God's blessings equally and alike." The U.S. could rectify its past injustices toward Korea should it help actualize this aspiration. Toward this end Roosevelt only had to grant Korea its "clear-cut independence." 45

\section{United States Preparation for Korea's Postwar Occupation}

United States officials, faced with the more immediate challenges of coordinating wars in both Europe and Asia, groped to find answers to Korean inquiries that they did not have by either publicly responding to them in vague terms or by ignoring them all together. Their inability to provide more concrete answers most likely stemmed from the indefiniteness of the "in due course" phrase, as well as their general ignorance of the Korea situation. Behind closed doors, however, different agencies had become quite active in considering Korea's concerns. The United States and Great Britain were coordinating an effort to produce a questionnaire that would gather information on Korea. ${ }^{46}$ The U.S. State Department had been busy interviewing people familiar with Korea-Americans who returned to the U.S. after Pearl Harbor, and later Korean POWs who had surrendered to the Allied forces while fighting in the Japanese military. ${ }^{47}$

45 "Shin to Roosevelt" (January 14, 1944), in Internal Affairs of Korea (1940-1944), vol. 4, 90-94.

46 See the file "Economic and Reconstruction," FO371, File 4320, British National Archives, Kew Gardens, Great Britain, for reports of discussions related to, and drafts of, this questionnaire. One report, titled "From D.C. to FO procedure for researching Korea" (July 18, 1944), justified their drafting of this questionnaire as follows: "In view of statement in Cairo Declaration that "the aforesaid three governments...become free and independent" it would seem advisable for signatory Governments to discuss with each other certain of the problems that may arise in connection with establishment of a free and independent Korea."

47 Interviews can be found among documents included in Yi, ed., Haebang chŏnhusa charyojip I, 160-235, 308-329. as well as in the George M. McCune (1908-1948) Collection, box 20. Yi's publication also includes Chapter X of the Joint Intelligence Study Publishing Board, "Report Joint Army-Navy Intelligence Study of 
Since the beginning of the war discussions had taken place over the feasibility of utilizing Koreans more effectively in the war efforts, in particular in special unconventional operations that would be coordinated by the Office of Strategic Services (OSS) to place Koreans behind enemy lines. ${ }^{48}$ After the Cairo conference these discussions contemplated how best to mold the document's vague promises into more concrete plans.

In November 1944, the question of postwar occupation became the subject of a report that considered when the United States could address the question of "in due course" duration. This report was one of a series of discussions that considered postwar Korea's "political problems." While copies of these reports are included within the George M. McCune Collection it is unclear as to the role that McCune played in drafting them. We can assume, however, that the process benefited from McCune's expertise at some stage. ${ }^{49}$ McCune's background qualified him as a possible author of these reports. He was arguably the leading authority on Korea in the U.S. government at the time. Raised in a prominent missionary family, McCune spent his formative years in P'yǒngyang before being sent to the United States to complete his university education. He completed a dissertation on Northeast Asian historical relations in 1941. ${ }^{50}$ The Japanese attack on Pearl Harbor interrupted his budding academic teaching career; he was granted a leave of absence from Occidental University to work for

Korea (Including Tsushima and Quelpart) April 1945, 264-295, and Charles W. McCarthy, Alvin F. Richardson, Raymond E. Cox, "State-War-Navy Coordinating Committee Utilization of Koreans in the War Effort," 253-263.

48 See Mark E. Caprio, "The Eagle Has Landed: Groping for a Korean Role in the Pacific War,' Journal of American-East Asian Relations 21 (2014): 5-33, for discussion on the efforts made to use Koreans in this capacity.

49 George M. McCune (1908-1948) Papers, Box 20. This draft does not contain the name(s) of its author(s), nor those of its editor(s).

50 "Korean Relations with China and Japan, 1800-1864," (PhD dissertation, University of California, Berkeley, 1941). For George McCune's biography see C. Martin Wilbur, “George McAfee McCune, June 16, 1908-November 5, 1948,' Far Eastern Quarterly 9, no. 2 (February 1950): 185-91. 
the government, first at the Office of Strategic Services (OSS), then at the Board of Economic Welfare, and finally at the State Department. After the war he returned to academia as professor of Korean history at Occidental University before moving to the University of California, Berkeley. He is best known for his contribution to the McCune-Reischauer Romanization system of the Korean language that the two scholars completed in 1938.

One particular report, titled "Korea: Political Problems: Factors Determining Interval Between Liberation and Independence of Korea," ${ }^{51}$ considered the pluses and minuses of three scenarios that analyzed by domestic and foreign conditions to determine the duration, as well as the optimum timing for informing the Korean people, for "in due course." The report began by addressing the primary domestic problem: the Korean people's weaknesses:

$\ldots$ it is true that the Korean people have the inherent capacity for self-rule, that they have cultural unity through a common heritage of race, language and tradition, and that they possess the natural economic resources for maintaining a viable economy. However, at the present time the Korean people lack some of the qualifications desirable to fit them for self-government: adequate experienced civil-servant personnel, sufficient mass experience in the forms of democratic government, trained technicians who can operate a modern Korean economy.

The author attributed the Korean people's shortcoming to their having endured over three decades of colonial rule under the Japanese, a period over which time the people had been prohibited by the Japanese from "developing an independent state." Their limitations extended to the ex-

51 "Korea: Political Problems: Factors Determining Interval Between Liberation and Independence of Korea" (November 27, 1944), The George M. McCune (19081948) Papers, Box 22. The hitherto cited information is all quoted from this report. 
tensive populations of Koreans living in exile: These people lacked both the qualities and the training needed to assume positions of leadership in postwar Korea.

In addition, there were external factors that required attention before the timing of Korea's complete independence could be determined. The report echoed the reasoning that Japan had used three decades previous to justify annexing the Korean peninsula, namely the threat that an independent Korea posed to the region.

The strategic position of Korea will undoubtedly produce rivalry between various powers for the control of Korea unless Korea develops a government of sufficient stability and efficiency to satisfy the interests of her neighbors. Even if Korea succeeds in forming a stable government neighboring powers with rival interests may compete for influence and may seriously endanger the security of the Far East. Korea with a population of only twentyfive million is obviously a small state in comparison with her neighbors and cannot be expected to stand alone. An effective international security organization must provide the basis for the maintenance of the independence and integrity of a new Korean state.

The difference in the Allied postwar plan and Japanese colonial subjugation was that the former appeared dedicated to strengthening Korea's position as an independent state rather than, in Japan's case, as an integrated and permanent extension of a bulging empire.

With Korea's domestic and foreign predicament in mind the report attempted to calculate duration. It recognized the difficulty of establishing such a timeframe during the war: The U.S. needed to "examine the capacity of the Korean people for self-government other than through the [primarily Japanese-generated] statistical records" then available to the Allies. The report estimated that, following Japan's surrender, it might take as long as six months for the U.S. to attempt to answer this question. With 
this in mind, the report then posed a number of possible approaches to establishing the timeframe for Korea's independence. One possibility would be to set a timeframe now in order to pacify the present Korean inquiries. This, however, risked angering the people later if this timeframe proved to be unreasonable. An alternative scenario would be to announce a tentative date for Korean independence, one contingent on the occupying administration and the Korean people meeting a defined set of criteria. Such flexibility might motivate the Korean people into meeting these criteria ahead of schedule. On the other hand, the lack of a set date might also frustrate the people into raising opposition to the U.S. occupation administration. A third scenario proposed the U.S. setting a date soon after arrival-the report advised six months. Doing so, however, might also raise Korean suspicions over the occupiers' intentions, as well as stimulate organization by opposition groups. In the minds of many Koreans, this report addressed a moot question: Any period of guidance that separated liberation from independence carried little weight.

The future of this report, whether it was revised further or if it guided occupation policy, is unknown. It appears certain, however, that the Soviet and then U.S. occupation forces that entered Korea in late August and early September had little idea as to how long they would be required to remain on the peninsula. At a time when the wars in Europe and Asia where approaching closure and the Allied leaders met to determine postwar issues in Yalta and then Potsdam, the decisions etched into the Cairo Communiqué appeared as formalized policy that generated minimal discussion. ${ }^{52}$ At these times the mere mention of Cairo sufficed as a code phrase for Korea's future occupation. For example, the Potsdam Declaration of July 1945 simply pledged that the "Cairo Declaration shall be car-

52 United States, Department of State, comp. "The Conferences at Yalta and Malta, 1945 " did contain a short section titled the "Post-war Status of Korea," that offered that Korea's trusteeship "should not be a one-state" operation, but that the U.S. should have "prominent ...strength." The underlining foundation of its postliberation, however, remained Allied occupation. 
ried out" before stating that the Allies planned to limit Japanese territory to "the islands of Honshu, Hokkaido, Kyushu, Shikoku and such minor islands as we determine." 53 While the document added detail to Japan's situation by delineating its territorial limitations, in Korea's case it simply reaffirmed that its immediate future had been decided nearly two years previous. It would not be until December1945, when the foreign ministers of Great Britain, the United States, and the Soviet Union met in Moscow, that a substantial discussion over Korea's future addressed the questions of duration and sovereignty.

The Postwar Legacy of the Cairo Communiqué

U.S.-directed occupations in Northeast Asia commenced a few weeks after the Japanese emperor declared Japan's intention to surrender. General Douglas MacArthur arrived to accept Japan's formal surrender at a ceremony held in Tokyo Bay on September 2, and to assume his position as Supreme Commander of the Allied Powers (SCAP). His authority extended to include southern Korea. In early September he issued instructions to the "People of Korea," a document that borrowed from the Cairo Communiqué both in spirit and rhetoric:

Having in mind the long enslavement of the people of Korea and the determination that in due course Korea shall be free and independent, the Korean people are assured that the purpose of the occupation is to enforce the Instrument of Surrender and to protect them in their personal and religious rights. In giving effect to these purposes, your active aid and compliance are required.

He then entered in Article II his direction that colonial-era employees "shall continue to perform their usual functions and duties" until further

53 For the text of the Potsdam Declaration see Young Hum Kim, East Asia's Turbulent Century (New York: Appleton-Century-Crofts, 1966), 297-98. 
notice. Although the general established the purpose of the occupation as to "protect [the Korean people] in their personal and religious rights," by enforcing the Instrument of Surrender upon the Japanese, he made no mention regarding the matter that most concerned the Korean people: that of duration. ${ }^{54}$

No formal attention was given to this matter, as well as that of trusteeship, until the following December, when at a meeting attended by the Foreign Ministers of the Soviet Union, Great Britain, and the United States in Moscow, there emerged a roadmap designed to realize the pledge entered into the Cairo Communiqué to deliver independence to the Korean state. The Moscow Decision instructed that a U.S.-Soviet Joint Commission would "consult with the Korean democratic parties and social organizations" to form a "provisional Korean government" to prepare the people for the formation of a permanent one to replace it. It continued:

It shall be the task of the Joint Commission with the participation of the provisional Korean democratic government and of the Korean democratic organizations to work out measures also for helping and assisting (trusteeship) the political, economic and social progress of the Korean people, the development of democratic self-government and the establishment of the national independence of Korea.

The document further stipulated that the Korean people would be subjugated to a "four-power trusteeship [to include representatives from the United States and the Soviet Union, as well as from Great Britain and

54 "Proclamation No. I by General of the Army Douglas MacArthur" (September 7, 1945), United States, Department of State, comp. Foreign Relations of the United States, Diplomatic Papers, British Commonwealth and the Far East, Vol. VI (1945), (Washington, DC: Government Printing Office), 1969), 1055. This direction initially intended, but later amended, to include Japan's top colonial officials, including Governor General Abe Nobuyuki. 
China] for a period of up to five years." The time period, according to Soviet documents, had been arrived at after the Soviet participants objected to a U.S. proposal that called for an up-to-ten-year trusteeship period. Even this truncated time-period, to most Koreans, was considered too long a period to expect them to extend their "aid and compliance." 55

The Joint Commission convened over 60 times between 1946-1947. However, the two superpowers proved unable to clear the hurdles that divided them to agree on which democratic parties and social organizations would be eligible to consult with the Joint Commission, a prerequisite for their advancing to the next stage, the formation of a united provisional Korean government. The Soviet Delegation insisted that anyone who refused to accept the Moscow Decision in total, including trusteeship, would be ineligible for participation in the process. The United States countered that, as protest was a fundamental right of members of a democratic society, those Koreans who disagreed with the process must be allowed full participation. At stake was political influence. Those most vocal in protesting trusteeship were among the leadership of southern Korea's extreme right wing, including Syngman Rhee and Kim Ku. Their elimination from the process would have dramatically tilted peninsular politics toward the left. Unable to reach agreement, the United States

55 See "TASS statement on the Korean Question" (January 23, 1946), reprinted in The Soviet Union and the Korean Question (Documents) (Moscow: Ministry of Foreign Affairs, 1948), 7-10. The United States representative at this meeting, Secretary of State James F. Byrnes, offered a chapter on the Moscow meeting in his memoirs but only a short paragraph on the Moscow Decision on Korea. The most important issues of the conference appear to have regarded discussion on the powers forming consensus on an international agreement on the use of atomic energy, the foreign troop situations in Iran and China, and other European matters. See James F. Byrnes, All in One Lifetime (New York: Harper and Brothers, 1958), Chapter 22. The Soviets were also disturbed upon learning that the southern Korean media had been reporting that it was the Soviets who had proposed trusteeship and the United States immediate independence. See Chŏng Yong Uk, "Yŏkpinondan," 287-322. 
turned the Korean issue over to the United Nations, a move to which the Soviet Union objected. This paved the way for separate elections in the South and North, their formation of separate states, the bloody civil war that they fought, and the two-Korean state division that persists to this day.

\section{Conclusion}

The three Allied leaders that met in Cairo would no doubt express surprise in learning that the final draft of the Cairo Communiqué, and particularly the short three-word phrase that they inserted at the last minute, continues to have such a powerful influence on the Korean peninsula to this day, decades later. The resilience of this phrase might not have been so stubborn had the parties involved focused more on the Korean peninsula and its native residents, and less on their own national interests. The British, in crafting the obtuse "in due course" phrase, appeared more concerned over the possible reaction that a more precise statement might have had on independence leaders within their empire. The actions of the two occupiers of the peninsula following Korea's liberation suggest their interests to have been more directed toward strengthening ideological bases in their respective zones than in promoting a true democracy to allow the Korean people to determine their political future. Korean parties that protested the Moscow Decision in general, and trusteeship in particular, can perhaps be forgiven for raising objections to foreign powers determining their country's fate. Korea, after all, had protected its sovereignty for centuries; though Koreans fought in Japanese armies, the people as a whole were not willing belligerents in the war. The actions of these Koreans, which proved to be a major impediment to the Joint Commission advancing the process, must be measured against the longterm effect that they had on Korea in the decades that followed. What led these Koreans to object to a process designed to advance their homeland to a unified and independent future?

The Allied powers justified Korea's need for a trusteeship-based occu- 
pation period in ways that resembled the reasons that the Japanese gave to explain their intrusions onto the Korean peninsula: An independent Korea attracted competition from its more powerful neighbors and thus threatened regional peace. A post-liberation occupation of Korea by the global powers was necessary to pacify the region. This postwar vision differed from the Japanese intentions in that it was understood to be transitoryKorea eventually would be granted its independence, whereas the Japanese saw their presence as permanent. Over the decades since the Korean people have demonstrated their capacity to administer their affairs, even against the occasional interference in their domestic matters by more powerful states. Yet, the peninsular division that grew from the spirit of an obtuse three-word phrase, "in due course," approaches its ninth decade, a period more than twice as long as the nearly four decades of Japanese colonial rule that it replaced in 1945.

\section{References}

Primary sources

1. British Foreign Office Papers. Tokyo: Japan Diet Library.

2. British National Archives. Kew Gardens, Great Britain.

3. Internal Affairs of Korea (1940-1944), Migukkukmu sŏng Hanguk kwanke munsǒ [Papers of the United States Department of State, Korea]. 23 volumes. Seoul: Wonjumunhwasa, 1993.

4. George M. McCune (1908-1948) Collection. Honolulu: University of Hawai'i, Center for Korean Studies, 2018.

5. Yi Kilsang, ed. Haebang chŏnhusa charyojip: Mikunjŏng chunbi charyo [Collection of United States Military Administrative Documents around the Time of Liberation]. Seoul: Wŏnju munhwasa, 1992. 


\section{Newspapers}

6. Asahi shinbun (Asahi Newspaper, Japanese)

7. Keijō ilbōo (The Keijō Daily, Japanese)

8. Korean Independence (English and Korean)

9. Taiwan nichi-nichi shinbun (The Taiwan Daily Newspaper, Japanese)

10. Tongnip sinmun (The Independent, Korean)

11. Voice of Korea (English)

Film

12. "The Cairo Conference. Video. 1943" <https://www.youtube.com/w atch?reload $=9 \& \mathrm{v}=\mathrm{TT} 16 \mathrm{RC} 43 \mathrm{~h} 7 \mathrm{~g}$ (accessed November 3, 2020).

Secondary Sources

13. Borton, Hugh. "American Presurrender Planning for Postwar Japan." Occasional Papers of The East Asian Institute. New York: Columbia University, 1967.

14. Byrnes, James F. All in One Lifetime. New York: Harper and Brothers, 1958.

15. "Cairo and Tehran." The Christian Century 60. (December 15, 1943): 1465.

16. Caprio, Mark E. "The Eagle Has Landed: Groping for a Korean Role in the Pacific War." Journal of American-East Asian Relations 21 (2014): 5-33.

17. . "The Politics of Trusteeship and the Perils of Korean Reunification." Seoul Journal of Korean Studies 32, no. 2 (December 2019): 263-91.

18. Chŏng Yong Uk. "Yŏkpinondan: 1945nyŏn mal 1946nyŏn ch'o sint'ak t'ongch'i p'atong kwa migunchŏng migunchŏn ŭi yŏron 
kongjak ŭl chungsim ŭro" [The United States Military Government and Fluctuations in Trusteeship Administration from Late 1945 to early 1946: A Focus on U.S. Public Opinion Maneuvering]. Yǒksa Pip’ŏngsa (February 2003): 287-322.

19. Churchill, Winston. The Second World War, Volume 5: Closing the Ring. London: Cassell and Company, 1951.

20. Grajdanzev, Andrew. Korea Looks Ahead. New York: American Council, Institute of Pacific Relations, 1944.

21. Heiferman, Ronald. The Cairo Conference of 1943: Roosevelt., Churchill, Chiang Kai-shek, and Madame Chiang. Jefferson: McFarland \& Company, 2001 (Kindle edition).

22. Herman, Arthur. Gandhi and Churchill: The Epic Rivalry that Destroyed an Empire and Forged Our Age. London: Bantam, 2009.

23. Kim, Young Hum. East Asia's Turbulent Century. New York: Appleton-Century-Crofts, 1966.

24. Kimball, Warren F. Forged in War: Roosevelt, Churchill, and the Second World War. New York: William Morrow and Company, 1997.

25. Liu, Xiaoyuan. A Partnership for Disorder: China, the United States, and Their Policies for the Postwar Disposition of the Japanese Empire, 1941-1945. Cambridge: Cambridge University Press, 2002.

26. Matray, James I. "Civil War of Sort: The International Origins of the Korean Conflict." In Korean War in Retrospect: Lessons for the Future, edited by Daniel Meador, 139-82. Lanham: University Press of America, 1998.

27. Pae Kyǒnghan. "Kairo hoedam esǒ ǔi Hanguk munje wa Jiang Jieshi" [Jiang Jieshi [Chiang Kai-shek] and the Korea Problem at the Cairo Conference]. Yǒksa Hakpo 224 (December 2014): 305-35.

28. Sainsbury, Keith. The Turning Point: Roosevelt, Stalin, Churchill, and Chiang Kai-Shek, 1943: The Moscow, Cairo, and Tehran Conferences. Oxford: Oxford University Press, 1986.

29. Soviet Union and the Korean Question (Documents). Moscow: Ministry of Foreign Affairs, 1948. 
30. Stewart, Maxwell S. "The Cairo Declaration." Far Eastern Survey 12, no. 25 (December 22, 1943): 241-42.

31. United States Department of State, comp. Foreign Records of the United States Diplomatic Papers 1945. Vol. VI: The British Commonwealth, The Far East, Washington, D.C.: Government Printing Office, 1969.

32. United States, Department of State, comp. Foreign Relations of the United States, Diplomatic Papers: The Conferences at Cairo and Teheran 1943. Washington, DC: Government Printing Office, 1961.

33. Wada Haruki and Pak Unjjin. "Kairo sǒn'ǒn kwa Ilbon yǒngt'o munje" [The Cairo Declaration and Japanese Territorial Issues]. Yǒn'go haebang yǒn'gu 5 (June 2013): 86-111.

34. Wilbur, C. Martin. "George McAfee McCune, June 16, 1908November 5, 1948." Far Eastern Quarterly 9, no. 2 (February 1950): 185-91.

35. Yi Chun-sik. Kim Kyu-sik [Kim Kyu-sik]. Seoul: Yoksa kongkan, 2014. 


\section{(Mis)-Interpretations of the 1943 Cairo Conference: The Cairo Communiqué and Its Legacy among Koreans During and After World War II}

In December of 1943, three leaders of the Allied forces gathered in Cairo, Egypt to discuss wartime and postwar issues. The Communiqué that they completed in the last of the four-days of meetings, however, reflected issues related to the postwar fate of the Japanese empire, rather than the wartime issues that had dominated their discussions. The rather obtuse phrase, "in due course," inserted to qualify the leaders' promise to deliver Korea its independence would gather significant importance only after the conference. It served as a cornerstone for Allied occupation policy planning and execution for future gatherings, while Koreans used it as a rallying point around which they protested Allied trusteeship policy both during and after the Pacific War. This disagreement contributed to the failure that the U.S. and Soviet experienced in their efforts to reunite the peninsula during their three-year occupations of southern and northern Korea. The legacy of this phrase continues in the divided peninsula to this day.

Keywords: "in due course," trusteeship, Cairo Communique, United States, Nationalist China, Great Britain, Soviet Union, reactions, Korean divisions 


\title{
< 국문초록 >
}

\section{3년 카이로회담의 오해와 이해: 2차세계대전과 그 이후 한국인들에게 남겨진 카이로선언과 그 유산}

\author{
마크 카프리오 (Rikkyo University)
}

1943년 12월, 이집트의 카이로에 모인 연합국의 세 수장은 전시와 전후 문제 처리에 대해 논의하였다. 그러나, 나흘간 이어진 회담의 마지막에 완성된 선언문은, 논의 대부 분을 이루었던 전시 문제보다는 전후 일본 제국의 운명에 대한 사안을 반영하였다. "적 당한 시기에"라는 꽤나 무딘 표현은 연합국 수장들이 한국에 독립을 선사하겠다는 약 속을 이행하기 위하여 삽입되었는데, 회담 이후가 되어서야 막대한 중요성을 얻었다. 이는 연합국에는 점령 방침을 계획하고 향후 소집을 실행하기 위한 주춧돌이 되었으나, 한국인에게는 이를 태평양전쟁과 그 후 연합국의 신탁 통치에 대한 반대 운동의 집합 지로 사용되었다. 이 의견의 불일치가 미국과 소련 양국이 3년간 한반도의 남쪽과 북 쪽을 점령하면서 한반도를 통일하고자 하였던 노력이 실패하는 원인이 되었다. 이 구 절의 유산은 현재까지도 분단된 반도에서 살아 숨쉬고 있다.

주제어: “적당한 시기에”, 신탁통치, 카이로선언, 미국, 중국 국민당, 영국, 소비에트 연방, 반응, 한반도 분단 